\title{
Posttranslational Regulation of Insulin-like Growth Factor Binding Protein-4 in Normal and Transformed Human Fibroblasts
}

\author{
Insulin-like Growth Factor Dependence and Biological Studies
}

\author{
Cheryl A. Conover, ${ }^{\star}$ Michael C. Kiefer, ${ }^{\star}$ and Jürgen Zapf \\ ${ }^{*}$ Endocrine Research Unit, Mayo Clinic, Rochester, Minnesota 55905; ${ }^{\ddagger}$ Chiron Corporation, Emeryville, California 94608 ; \\ and ${ }^{\S}$ Metabolic Unit, Department of Medicine, University Hospital, CH-8091, Zurich, Switzerland
}

\begin{abstract}
Insulin-like growth factor binding protein-4 (IGFBP-4) is a 24-26-kD protein expressed by a variety of cell types in vivo and in vitro. Treatment of normal adult human fibroblasts with $10 \mathrm{nM}$ insulin-like growth factor II (IGF-II) for $24 \mathrm{~h}$ resulted in an $85 \%$ decrease in endogenous IGFBP-4, as assessed by Western ligand blot analysis of the conditioned medium. Incubation of human fibroblast-conditioned medium (HFCM) with IGF-II under cell-free conditions led to a similar loss of IGFBP-4. This posttranslationally regulated decrease in IGFBP-4 appeared to be due to a protease in HFCM: $(a)$ It could be prevented with specific protease inhibitors or incubation at $4^{\circ} \mathrm{C} ;(b)$ proteolysis of recombinant human ( $\left.r h\right)$ IGFBP-4 required HFCM; $(c)$ immunoblotting and radiolabeling confirmed cleavage of IGFBP-4 into 18- and 14-kD IGFBP-4 fragments. The protease was specific for IGFBP-4, and was strictly dependent on IGFs for activation. IGF-II was the most effective of the natural and mutant IGFs tested, inducing complete hydrolysis of rhIGFBP-4 at a molar ratio of 0.25:1 (IGF/IGFBP-4). Simian virus 40-transformed adult human fibroblasts also expressed IGFBP-4 and IGFBP-4 protease, as well as an inhibitor of IGFBP-4 proteolysis. In biological studies, intact rhIGFBP-4 potently inhibited IGF-I-stimulated $\left[{ }^{3} \mathrm{H}\right.$ ]aminoisobutyric acid uptake, whereas proteolyzed rhIGFBP-4 had no inhibitory effect. In conclusion, these data provide evidence for a novel IGF-dependent IGFBP-4-specific protease that modifies IGFBP-4 structure and function, and indicate a preferential role for IGF-II in its activation. Posttranslational regulation of IGFBP-4 may provide a means for cooperative control of local cell growth by IGF-I and IGF-II. (J. Clin. Invest. 1993. 91:1129-1137.) Key words: insulin-like growth factors I and II $\bullet$ insulin-like growth factor binding protein $-4 \cdot$ protease $\cdot$ protease inhibitor
\end{abstract}

\section{Introduction}

In recent years, six distinct insulin-like growth factor binding proteins (IGFBPs) ${ }^{1}$ have been identified and designated as

Address reprint requests to Dr. Cheryl Conover, Endocrine Research Unit, Mayo Clinic, 5-164 West Joseph, Rochester, MN 55905.

Received for publication 8 June 1992 and in revised form 17 September 1992.

1. Abbreviations used in this paper: AIB, aminoisobutyric acid; HFCM, human fibroblast-conditioned medium; IGF, insulin-like growth factor; IGFBP, IGF binding protein; SFM, serum-free medium; SV40, simian virus 40 .

J. Clin. Invest.

(c) The American Society for Clinical Investigation, Inc.

0021-9738/93/03/1129/09 \$2.00

Volume 91, March 1993, 1129-1137
IGFBP-1 through IGFBP-6 (1-8). The importance of these IGFBPs lies in their potential to modify the diverse metabolic and mitogenic effects of insulin-like growth factor (IGF) I and II (9). IGFBPs are present in serum and other biological fluids and are secreted by a variety of cells in culture, suggesting critical modulation of local as well as systemic action of the IGFs $(10,11)$. Therefore, knowledge of the regulation of the different IGFBPs is fundamental to our understanding of IGF responsiveness at the cellular level. At present, the factors affecting IGFBP bioavailability are not completely understood. IGFBP-1, IGFBP-2, and IGFBP-3 mRNA expression can be regulated by various hormones and growth factors (12-17). Additionally, IGFBP-1 and IGFBP-3 have been shown to undergo posttranslational modifications, such as phosphorylation and proteolytic processing, that result in altered bioactivity (18-21).

Little is known about the regulation of IGFBP-4. IGFBP-4 is a $24-26-\mathrm{kD}$ protein, originally isolated from the conditioned medium of human bone cells and rat serum $(6,7)$. It is secreted by a number of different cell types in vitro and IGFBP-4 mRNA is expressed in a variety of tissues $(6,7,22-29)$. Although its precise biological function is unknown, IGFBP-4 has been implicated as a potent inhibitor of IGF action in bone and in other systems $(8,22,26,30-32)$. Recently, we reported that, in contrast to an increase in IGFBP-3, treatment of normal human fibroblasts and human osteoblast-like cells with IGF-I or IGF-II led to a marked reduction in the levels of 24 . kD IGFBP-4 detected in the cell-conditioned medium (25, 33). An IGF-induced decrease in human fibroblast-derived IGFBP-4 was also described by Neely and Rosenfeld (34) and Clemmons et al. (27). Data from these studies indicated that this effect did not require IGF binding to type I or type II IGF receptors present on the cells. Interestingly, simian virus 40 (SV40)-transformed human fibroblasts, SV40-transformed human osteoblasts, a human epidermal squamous cell carcinoma line, and various osteosarcoma cell lines secrete $24-\mathrm{kD}$ IGFBP, the medium levels of which are not affected by treatment of cells with IGF-I or IGF-II $(25,33,34)$.

In this study, we examined the mechanism by which IGFs regulate IGFBP-4 in cultured human fibroblasts. We present evidence for an IGF-activated protease that is specific for IGFBP-4 and that modifies IGFBP-4 structure and function. Furthermore, our data suggest involvement of an inhibitor, dominant in the transformed fibroblasts, that blocks proteolysis of IGFBP-4.

\section{Methods}

Materials. Recombinant human IGF-I and IGF-II were purchased from Amgen Biologicals (Thousand Oaks, CA) and Bachem, Inc. (Torrance, CA), respectively. des(1-3)IGF-I was from KabiGen (Stockholm, Sweden). IGF-I analogues obtained by site-directed mutagenesis $\left[\mathrm{Ser}^{24}\right] \mathrm{IGF}-\mathrm{I},\left[1-27, \mathrm{Gly}_{4}, 38-70\right] \mathrm{IGF}-\mathrm{I}$, and [Gln ${ }^{3}, \mathrm{Ala}^{4}$, 
$\mathrm{Tyr}^{15}$, Leu $\left.{ }^{16}\right]$ IGF-I([QAYL]IGF-I), were generous gifts of Dr. M. Cascieri (Merck Sharp \& Dohme, Rahway, NJ). Recombinant human (rh) IGFBP-4, rhIGFBP-5, and rhIGFBP-6 were produced in yeast and purified by IGF-I affinity chromatography and HPLC (8). IGFBP-4 antiserum was generated against rhIGFBP-4 in rabbits by Babco (Berkeley, CA), and is highly specific for IGFBP-4 (35). Crystalline human insulin was provided by Eli Lilly \& Co. (Indianapolis, IN) and human growth hormone and rhIGFBP-3 by Genentech, Inc. (South San Francisco, CA). Epidermal growth factor was obtained from Collaborative Research Inc. (Lexington, MA), endoglycosidase F was from Calbiochem-Behring Corp. (La Jolla, CA), and tissue culture supplements were from Gibco Laboratories (Grand Island, NY). Aprotinin was obtained from Boehringer Mannheim Biochemicals (Indianapolis, IN). BSA (fraction V, RIA grade), steroid hormones, and all other inhibitors were purchased from Sigma Chemical Co. (St. Louis, MO).

Cell-conditioned medium. Human dermal fibroblasts from normal adult donors (GM03652B) and SV40-transformed human fibroblasts (GM00637E) were purchased from the Human Genetic Mutant Cell Repository (Camden, NJ). Fibroblasts were cultured in DME supplemented with $100 \mathrm{U} / \mathrm{ml}$ penicillin, $100 \mu \mathrm{g} / \mathrm{ml}$ streptomycin, and $4 \mathrm{mM}$ glutamine, and containing 10\% supplemented calf serum (HyClone Laboratories, Logan, UT).

At confluency, fibroblasts were washed twice and preincubated in a 1:1 mixture by volume of Waymouth's medium to DME plus $0.1 \%$ BSA serum-free medium (SFM) for $24 \mathrm{~h}$. The cells were then washed and the medium changed to SFM for $72 \mathrm{~h}$. At the end of the incubation period, the cell-conditioned medium was centrifuged at $2,000 \mathrm{~g}, 4^{\circ} \mathrm{C}$ for $30 \mathrm{~min}$ and stored frozen at $-70^{\circ} \mathrm{C}$. Medium conditioned by normal human fibroblasts is referred to as HFCM; medium conditioned by SV40-transformed human fibroblasts is referred to as SV40-HFCM.

Cell-free incubation. $50 \mu \mathrm{l}$ of cell-conditioned medium (HFCM or SV40-HFCM) were incubated in a microfuge tube with experimental additions ( or equivalent volume of SFM) at $37^{\circ} \mathrm{C}$ for $24 \mathrm{~h}$ unless otherwise indicated.

Cell culture incubation for inhibitor studies. SV40-transformed human fibroblasts were plated in 24-multiwells (Costar, Cambridge, MA) and grown to confluency. Cells were washed twice and preincubated with SFM for $24 \mathrm{~h}$. At this time the cells were again washed and then incubated for $24 \mathrm{~h}$ with HFCM with or without addition of cycloheximide and IGF-II.

Western ligand blot analysis. Unreduced conditioned medium samples $(50 \mu \mathrm{l})$ were processed by SDS-PAGE using a $7.5-15 \%$ linear gradient, and separated proteins were electroblotted onto nitrocellulose filters using a BioTrans Unit (Gelman Sciences, Inc., Ann Arbor, MI). Filters were blocked, labeled with ${ }^{125} \mathrm{I}-\mathrm{IGF}-\mathrm{I}$ overnight at $4^{\circ} \mathrm{C}$, and visualized by autoradiography, according to the method of Hossenlopp et al. (36) and as described in previous publications $(23,33)$. Unstained $M_{\mathrm{r}}$ standards (BioRad Laboratories, Richmond, CA) were processed in parallel, and proteins were stained using India ink (37). Films were scanned with an UltroScan XL laser densitometer; absorbance curves were integrated and compared, and molecular size was determined, using GelScan XL software (Pharmacia LKB Biotechnology Inc., Piscataway, $\mathrm{NJ}$ ).

Western immunoblot analysis. Reduced (+100 mM DTT) or unreduced samples were electrophoresed using a 10-20\% linear gradient and transferred as described above for Western ligand blots. Filters were blocked with $3 \%$ BSA overnight at $4^{\circ} \mathrm{C}$, incubated $2 \mathrm{~h}$ with IGFBP-4 antiserum ( $1: 500$ final dilution), and then incubated $2 \mathrm{~h}$ with goat anti-rabbit IgG-alkaline phosphatase conjugate ( $1: 300$ final dilution). Antigen-antibody reactions were visualized using Vectastain $\mathrm{ABC}$ immunoblotting reagents following manufacturer's instructions (Vector Laboratories, Burlingame, CA).

Radiolabeled IGFBP-4. rhIGFBP-4 was iodinated by a modification of the chloramine-T method (38) and reaction products separated on a G-75 Sephadex column (Pharmacia). ${ }^{125}$ I-rhIGFBP-4 $(\sim 25,000$ $\mathrm{cpm}$ ) was incubated in cell-free HFCM for $6 \mathrm{~h}$ at $37^{\circ} \mathrm{C}$ with or without IGF-II. Unreduced samples were fractionated by SDS-PAGE using a
10-20\% linear gradient. Gels were stained with Coomassie Blue, dried, and exposed to film.

Soluble IGF binding assay. rhIGFBP-4 $(0.08 \mathrm{nM})$ was incubated with ${ }^{125}$ I-IGF-I $(30,000 \mathrm{cpm}, \sim 0.02 \mathrm{nM})$ and various concentrations of unlabeled IGF overnight at $4^{\circ} \mathrm{C}$. (The concentration of rhIGFBP-4 was based on a preliminary titration experiment to determine a concentration near but not at the plateau of maximal radioligand binding.) Activated charcoal ( $1 \%$ ) containing $0.2 \mathrm{mg} / \mathrm{ml}$ protamine sulfate was added, and the samples were centrifuged at $4^{\circ} \mathrm{C}$ to separate bound from free IGF-I $(23,24)$. Binding in buffer alone was subtracted from the total bound radioactivity to determine specific binding.

Aminoisobutyric acid (AIB) uptake. $\left[{ }^{3} \mathrm{H}\right] \mathrm{AIB}$ uptake was determined as described previously $(33,39,40)$. Confluent bovine fibroblasts ( 24 multiwells) were washed three times with HBSS containing $1.75 \mathrm{~g} / 1 \mathrm{NaHCO}_{3}, 20 \mathrm{mM}$ Hepes, $\mathrm{pH} 7.4$, and $0.1 \%$ BSA. The medium was changed to $2 \mathrm{nM}$ IGF-I in $450 \mu$ l HBSS buffer plus the indicated experimental additions (in $50 \mu \mathrm{l}$ of $\mathrm{HFCM}$ ), and the monolayers incubated at $37^{\circ} \mathrm{C}$ for $6 \mathrm{~h} .\left[^{3} \mathrm{H}\right] \mathrm{AIB}(0.5 \mu \mathrm{Ci} / \mathrm{ml}, 8 \mu \mathrm{M})$ was added and the incubation was continued for $12 \mathrm{~min}$. Cultures were placed on ice and washed quickly four times with cold PBS. Monolayers were solubilized in $0.25 \mathrm{~N} \mathrm{NaOH}$ and aliquots were taken for liquid scintillation counting. Results are expressed as percentage of total counts in the incubation medium which were taken up by the cells.

Statistics. Statistical comparisons were performed using analysis of variance and the Scheffe test for multiple comparisons. Results are considered statistically significant at $P<0.05$.

\section{Results}

IGF regulation of IGFBP-4 in normal human fibroblasts. Under control serum-free culture conditions, normal adult human fibroblasts secrete various IGFBPs with apparent $M_{\mathrm{r}}$ of $42,38,36,32,28$, and $24 \mathrm{kD}$, as assessed by Western ligand blotting with ${ }^{125} \mathrm{I}-\mathrm{IGF}-\mathrm{I}$ ( Fig. $1 A$ ). The $38 / 42-\mathrm{kD}$ IGF binding

\section{(A) Cell Culture Cell-free}

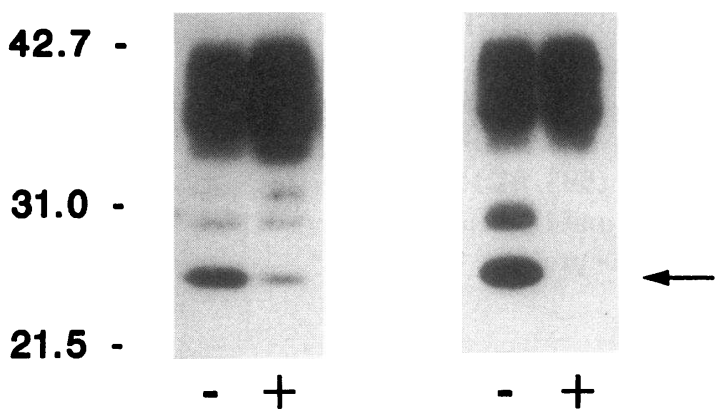

Figure 1. Western ligand blot of IGFBPs in HFCM: effect of IGF-II in cell culture and cell-free incubation. $(A)$ Cell culture: human fibroblasts were plated in 24 multiwells and grown to confluency. Confluent cultures were washed and incubated $24 \mathrm{~h}$ at $37^{\circ} \mathrm{C}$ in $500 \mu \mathrm{l}$ SFM without ( - ) or with $(+) 10 \mathrm{nM}$ IGF-II. Medium was collected at the end of this incubation period. $(B)$ Cell-free: medium was collected from human fibroblasts incubated with SFM for $72 \mathrm{~h}$ (referred to as HFCM in the text), and then incubated under cell-free conditions without $(-)$ or with $(+) 10 \mathrm{nM}$ IGF-II for $24 \mathrm{~h}$ at $37^{\circ} \mathrm{C}$. Medium samples $(50 \mu \mathrm{l})$ were electrophoresed through a nonreducing SDS-polyacrylamide gel (7.5-15\% linear gradient) and separated proteins were transferred onto nitrocellulose; after incubation with ${ }^{125}$ I-IGF-I, filter-immobilized IGFBPs were identified by autoradiography, as described in Methods. The migration positions of unstained molecular size markers (in $\mathrm{kD}$ ) are shown on the left. The arrow on the right indicates 24-kD IGFBP-4. 
doublet and the 24-kD IGFBP form are predominant, and have been identified as IGFBP-3 and IGFBP-4, respectively (33, 34, 41). In addition, 28-kD IGFBP is reduced to $24 \mathrm{kD}$ with endoglycosidase $F$ treatment (data not shown), and likely represents glycosylated IGFBP-4 $(5,26,41)$. Treatment of human fibroblasts with $10 \mathrm{nM}$ IGF-II for $24 \mathrm{~h}$ under serum-free culture conditions resulted in decreased medium IGFBP-4 (17\% of control levels) and increased levels of IGFBP-3 (2.7fold), in accord with our earlier description of IGF regulation of IGFBPs in human fibroblasts (33). Moreover, incubation of control HFCM with IGF-II for $24 \mathrm{~h}$ at $37^{\circ} \mathrm{C}$ without cells resulted in the specific loss of $24-$ and $28-k D$ IGFBP-4 (Fig. $1 B$ ). During this cell-free incubation, there was no decrease in IGFBP-4 in the absence of IGF-II. Furthermore, IGF-II did not alter IGFBP-3 levels and had no effect on other IGFBPs in HFCM. In time- and temperature-dependence studies $(n=3)$, IGFBP-4 in HFCM was decreased $73-82 \%$ within $2 \mathrm{~h}$ and was undetectable by $6 \mathrm{~h}$ of $37^{\circ} \mathrm{C}$ cell-free incubation with IGF-II; no loss of IGFBP-4 occurred with IGF-II when incubations were carried out at $4^{\circ} \mathrm{C}$ (data not shown). Addition of insulin $(100 \mathrm{nM})$, growth hormone $(1 \mu \mathrm{g} / \mathrm{ml})$, epidermal growth factor $(10 \mathrm{nM})$, dexamethasone ( $100 \mathrm{nM}), \beta$-estradiol $(1 \mu \mathrm{M})$, or progesterone $(1 \mu \mathrm{M})$ to cultured cells or to cell-free conditioned medium had no effect on IGFBP-4 levels (data not shown).

IGF-II, IGF-I, and various structural analogues of IGF-I were compared in their ability to modulate IGFBP-4 levels. Cell-free HFCM was incubated with or without $10 \mathrm{nM}$ of each peptide for $24 \mathrm{~h}$ at $37^{\circ} \mathrm{C}$ and the samples analyzed by Western ligand blot (Fig. 2). IGF-I, IGF-II, [Ser ${ }^{24}$ ]IGF-I, and des( 13)IGF-I each produced near complete loss of detectable IGFBP-4 in HFCM; [1-27, Gly 4 , 38-70] reduced IGFBP-4 levels $\sim 50 \%$ and [QAYL] IGF-I had no effect. IGF-II was consistently found to be the most effective IGF. In three experiments, the relative decrease in IGFBP-4 induced by $5 \mathrm{nM}$ of peptide was (mean \pm SE) $95 \pm 1 \%$ (IGF-II), $83 \pm 4 \%$ (IGF-I), $82 \pm 4 \%$ ([Ser $\left.{ }^{24}\right]$ IGF-I ), 61 $\pm 8 \%$ (des(1-3)IGF-I), and 35 $\pm 5 \%$ ([1-27, $\left.\mathrm{Gly}_{4}, 38-70\right] \mathrm{IGF}-\mathrm{I}$ ).

Effect of protease inhibitors on IGF regulation of IGFBP-4. Results of the cell-free experiments described above suggested that human fibroblasts may secrete an IGFBP-4-specific protease that is dependent upon IGFs for activation. Therefore, we tested various protease inhibitors on their ability to prevent IGF-II-induced decreases in IGFBP-4 in cell-free HFCM. EDTA and 1,10 phenanthroline, agents that complex divalent

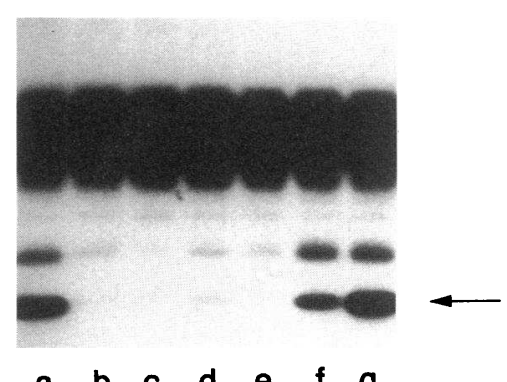

Figure 2. Regulation of IGFBP-4 in cell-free conditioned medium by IGF-II, IGF-I, and IGFI analogues. Cell-free HFCM was incubated with 10 nM IGF-I (lane $b$ ), IGF-II (lane $c$ ), des( 1-3)IGF-I (lane $d$ ), [Ser $\left.{ }^{24}\right]$ IGF-I (lane $e$ ), $\left[1-27, \mathrm{Gly}_{4}, 28-70\right]$ IGF-I (lane $f$ ), [QAYL]. IGF-I (lane $g$ ), or an

equivalent amount of SFM (lane $a$ ) for $24 \mathrm{~h}$ at $37^{\circ} \mathrm{C}$. Samples were analyzed by Western ligand blot using ${ }^{125} \mathrm{I}-\mathrm{IGF}-\mathrm{I}$, as described in Fig. 1. The arrow indicates 24-kD IGFBP-4.
Table I. Effect of Protease Inhibitors on IGF-II Regulation of IGFBP-4 during Cell-free Incubation

\begin{tabular}{lcc}
\hline \multicolumn{1}{c}{ Protease inhibitor } & Concn. & $\begin{array}{c}\text { IGFBP-4 band intensity } \\
\text { (percentage of control) }\end{array}$ \\
\hline None & & 3 \\
EDTA & $5 \mathrm{mM}$ & 100 \\
& $2 \mathrm{mM}$ & 70 \\
1,10 phenanthroline & $5 \mathrm{mM}$ & 93 \\
& $1 \mathrm{mM}$ & 61 \\
Benzamidine & $0.1 \mathrm{mM}$ & 10 \\
& $50 \mathrm{mM}$ & 94 \\
Aprotinin & $5 \mathrm{mM}$ & 28 \\
PMSF & $2 \mathrm{mg} / \mathrm{ml}$ & 8 \\
& $10 \mathrm{mM}$ & 14 \\
Antipain & $2 \mathrm{mM}$ & $<1$ \\
Soybean trypsin inhibitor & $2.5 \mathrm{mM}$ & $<1$ \\
& $2 \mathrm{mg} / \mathrm{ml}$ & $<1$ \\
\hline
\end{tabular}

Cell-free HFCM $(50 \mu \mathrm{l})$ was incubated for $24 \mathrm{~h}$ at $37^{\circ} \mathrm{C}$ with $10 \mathrm{nM}$ IGF-II and the indicated protease inhibitors. The samples were then analyzed by Western ligand blotting using ${ }^{125}$ I-IGF-I as described in Fig. 1. * IGFBP-4 band intensity was quantitated by scanning densitometry, and results are expressed as percentage of control (i.e., values in HFCM incubated without IGF-II).

cations, blocked IGF-induced decreases in IGFBP-4 (Table I). At high concentrations, benzamidine was also effective in inhibiting IGFBP-4 proteolytic activity, but other serine protease inhibitors (aprotinin, antipain, phenylmethylsulfonyl fluoride, and soybean trypsin inhibitor) had little or no effect at the concentrations tested.

Detection of IGFBP-4 fragments. We further investigated IGF-II regulation of IGFBP-4 using recombinant human IGFBP-4 (rhIGFBP-4). In initial experiments, rhIGFBP-4 ( 50 $\mathrm{ng} \cong 40 \mathrm{nM})$ was incubated with or without IGF-II ( $10 \mathrm{nM})$ for $24 \mathrm{~h}$ at $37^{\circ} \mathrm{C}$ in the absence or presence of cell-free HFCM. As shown in the Western ligand blot of Fig. 3, 24-kD rhIGFBP4 was stable during the $24 \mathrm{~h}$ incubation in SFM (lane $a$ ) or in HFCM (lanes $c, e$, and $g$ ). IGF-II had no effect on rhIGFBP-4 in the absence of HFCM, but decreased rhIGFBP-4 50\%, 88\%, and $97 \%$ when HFCM was present as $10 \%, 40 \%$, and $80 \%$ (lanes $d, f$, and $h$, respectively) of the total incubation volume. Under these same conditions, IGF-II had no effect on IGFBP-1 (from $\mathrm{HepG}_{2}$ cells [1, 23]), IGFBP-2 (from BRL3A2 cells [3, 23]), rhIGFBP-3, rhIGFBP-5, or rhIGFBP-6 (data not shown $)^{2}$

The availability of rhIGFBP-4 and IGFBP-4 antiserum allowed us to assess the nature of IGF-II-regulated IGFBP-4 by Western immunoblotting (Fig. 4). In samples electrophoresed under nonreducing conditions, a single immunoreactive band at $24 \mathrm{kD}$ was detected in samples containing $100 \mathrm{ng}(\sim 80$ $\mathrm{nM}$ ) rhIGFBP-4 and HFCM but no IGF-II. Inclusion of $10 \mathrm{nM}$ IGF-II resulted in the complete loss of immunoreactive $24-\mathrm{kD}$ IGFBP- 4 and the appearance of faint bands at 18 and $14 \mathrm{kD}$.

2. Western ligand blotting was performed using ${ }^{125}$ I-IGF-II as well as ${ }^{125}$ I-IGF-I in order to detect IGFBP-6, which has low affinity for IGF-I (8). 


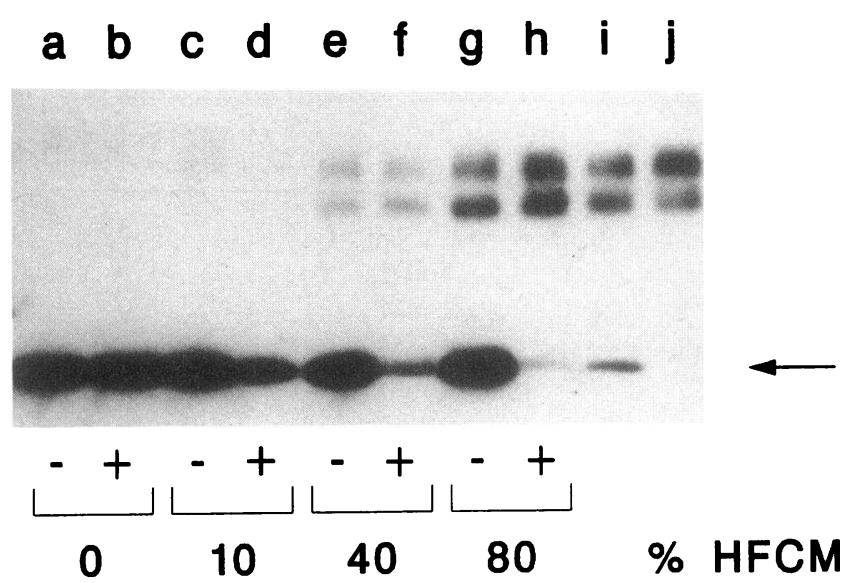

Figure 3. IGF-II regulation of rhIGFBP-4. Recombinant human IGFBP-4 (rhIGFBP-4, $50 \mathrm{ng}$ ) was incubated under cell-free conditions without (-) or with (+) $10 \mathrm{nM}$ IGF-II for $24 \mathrm{~h}$ at $37^{\circ} \mathrm{C}$ in a total volume of $50 \mu$, which included no HFCM (lanes $a$ and $b$ ), $10 \%$ HFCM (lanes $c$ and $d$ ), 40\% HFCM (lanes $e$ and $f$ ), or $80 \%$ HFCM (lanes $g$ and $h$ ). Lanes $i$ and $j$ represent HFCM with no rhIGFBP-4. The arrow indicates 24-kD IGFBP-4.

These bands most likely represent proteolytic fragments of IGFBP-4. With disulfide bond reduction, intact rhIGFBP-4 migrated at $32 \mathrm{kD}$. IGF-II-induced loss of this form again coincided with the appearance of 18- and 14-kD immunoreactive fragments. 18-kD IGFBP-4 was variably seen in untreated HFCM and may reflect a low level of proteolysis induced by endogenous IGF peptides secreted during culture $(42,43)$. The IGFBP-4 antiserum did not cross-react with $100 \mathrm{ng}$ of rhIGFBP-3, -5 , and -6 or with IGFBP-1 and IGFBP- 2 in cellconditioned medium (data not shown).

Products of IGFBP-4 proteolytic activity were also studied using radiolabeled rhIGFBP-4. As shown in Fig. 5, incubation of ${ }^{125}$ I-IGFBP-4 with HFCM and IGF-II resulted in a $76 \%$ decrease in intact IGFBP-4 and the generation of labeled fragments with estimated $M_{\mathrm{r}}$ of 18 and $14 \mathrm{kD}$. There was no signifi-

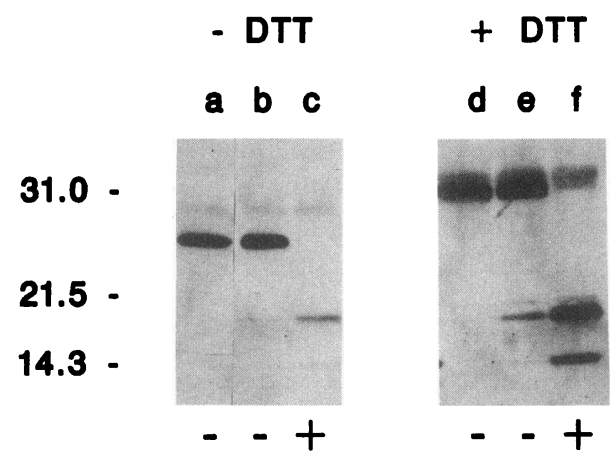

Figure 4. Immunoblot analysis using IGFBP-4 antiserum. rhIGFBP-4 (100 ng) in $50 \mu \mathrm{l}$ of HFCM was incubated under cell-free conditions without (-) or with (+) $10 \mathrm{nM}$ IGF-II for $24 \mathrm{~h}$ at $37^{\circ} \mathrm{C}$ (lanes $b, c$, $e$, and $f$ ). Lanes $a$ and $d$ represent $100 \mathrm{ng}$ of rhIGFBP-4 in unconditioned medium and with no incubation. Reduced (+DTT) or unreduced (-DTT) samples were electrophoresed on a 10-20\% gradient SDS-polyacrylamide gel, and transferred to nitrocellulose, and the filter was incubated with antiserum to IGFBP-4 (1:500 dilution), as described in Methods. Migration positions of unstained molecular size markers (in $\mathrm{kD}$ ) are shown on the left.

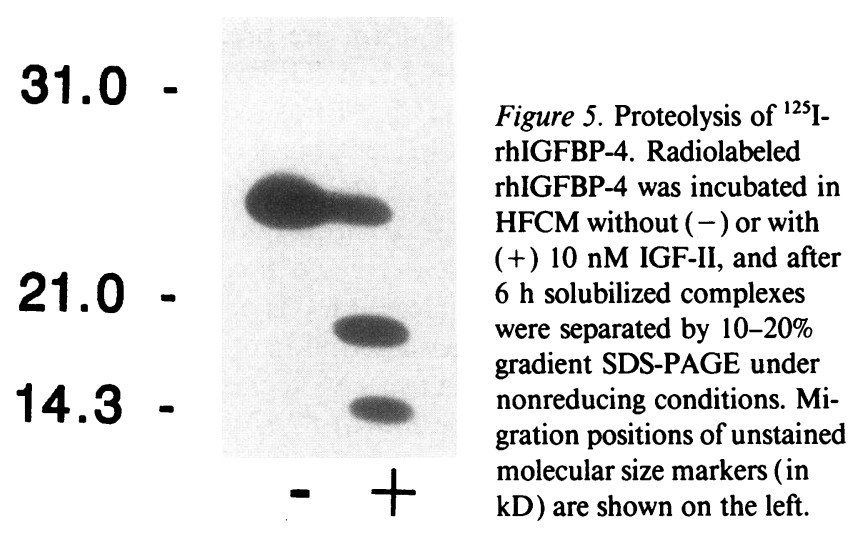

cant breakdown of ${ }^{125}$ I-rhIGFBP-4 during incubation in the absence of IGF-II.

$I G F$ binding to and regulation of rhIGFBP-4. IGF-I and IGF-II were equipotent in competing for ${ }^{125}$ I-IGF-I binding to $0.08 \mathrm{nM}$ rhIGFBP-4; $50 \%$ displacement was seen with $0.05 \mathrm{nM}$ unlabeled IGF-I or IGF-II. [1-27, $\left.\mathrm{Gly}_{4}, 28-70\right]$ IGF-I was twofold, and des( 1-3)IGF-I was 30-fold less potent than IGF-I and IGF-II in competing for ${ }^{125}$ I-IGF-I binding to rhIGFBP-4. Thus, half-maximal displacement of ${ }^{125}$ I-IGF-I binding to rhIGFBP-4 was achieved at a molar ratio (IGF/rhIGFBP-4) of 0.6:1 for IGF-I and IGF-II, 1.1:1 for [1-27, Gly, $28-70]$ IGF-I, and 19:1 for des (1-3)IGF-I (Fig. 6). In comparison, at a 0.25:1 molar ratio (IGF/rhIGFBP-4) IGF-II, IGF-I, and des(13)IGF-I were capable of inducing marked proteolysis of rhIGFBP-4, decreasing rhIGFBP-4 levels $97 \%, 88 \%$, and $74 \%$, respectively (Table II). Incubations with these three IGFs and

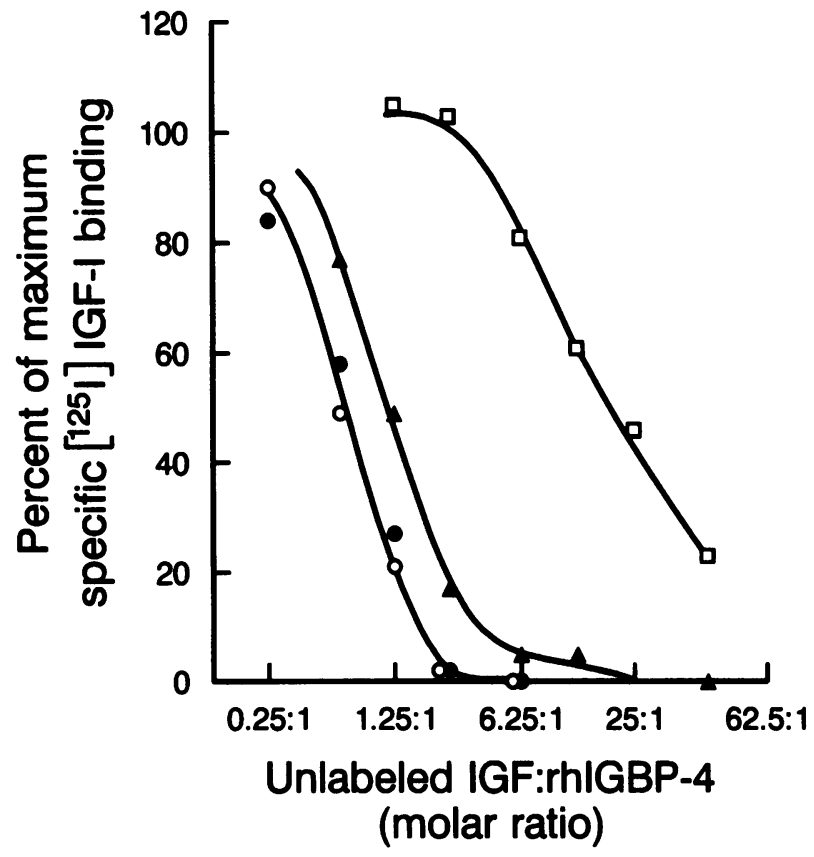

Figure 6. Competitive inhibition of ${ }^{125}$ I-IGF-I binding to rhIGFBP-4 by unlabeled IGF-II, IGF-I, and IGF-I analogues. Various concentra-

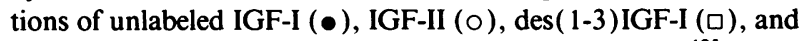
[1-27,Gly $\left.{ }_{4}, 28-70\right]$ IGF-I $(\triangle)$ were added to compete for ${ }^{125}$ I-IGF-I binding to $0.08 \mathrm{nM}$ rhIGFBP-4, as described in Methods. Results are the means of three experiments, expressed as percent of maximum specific ${ }^{125}$ I-IGF-I binding to rhIGFBP-4 $(33 \pm 3 \%)$. 
Table II. Regulation of rhIGFBP-4 Proteolysis by IGF-II, IGF-I, and IGF-I Analogues

\begin{tabular}{lrr}
\hline & \multicolumn{2}{c}{ rigFBP-4 (percent of } \\
\cline { 2 - 3 } \multicolumn{1}{c}{ IGF } & $0.25: 1$ & $1: 1$ \\
\cline { 2 - 3 } control) & \\
\hline IGF-I & 12 & 4 \\
IGF-II & 3 & $<1$ \\
des(1-3)IGF-I & 26 & 8 \\
{$\left[1-27\right.$, Gly $\left._{4}, 28-70\right]$ IGF-I } & 56 & 45 \\
\hline
\end{tabular}

* rhIGFBP-4 (20 nM) was incubated for $24 \mathrm{~h}$ at $37^{\circ} \mathrm{C}$ in $50 \mu \mathrm{l} \mathrm{HFCM}$ with the indicated IGFs at $5 \mathrm{nM}$ or $20 \mathrm{nM}$ for a molar ratio (IGF/ rhIGFBP-4) of $0.25: 1$ or $1: 1$. The samples were then analyzed by Western ligand blotting using ${ }^{125} \mathrm{I}$-IGF-I, as described in Fig. 1. rhIGFBP-4 band intensity was quantitated by scanning densitometry, and results expressed as percentage of control (i.e., no added IGF).

rhIGFBP-4 at a 1:1 molar ratio produced $>90 \%$ reductions in rhIGFBP-4 levels. [1-27, Gly $\left._{4}, 28-70\right]$ IGF-I was considerably less effective under these conditions, producing a $44-55 \%$ decrease in rhIGFBP-4.

$I G F$ regulation of IGFBP-4 in SV40-transformed human fibroblasts. SV40-transformed human fibroblasts also secrete 38/42-kD IGFBP-3 and a 24-kD IGFBP. As shown in Fig. $7 A$, treatment of these cell cultures with $10 \mathrm{nM}$ IGF-II markedly increased IGFBP-3 (sixfold), but did not alter levels of 24-kD IGFBP, similar to our previous findings (33). It was possible that these cells produce negligible amounts of IGF-dependent IGFBP-4 protease and/or a variant of IGFBP-4 that is resistant to proteolysis. However, incubation of SV40-HFCM with IGFII in a cell-free system resulted in a $98 \%$ decrease in $24-\mathrm{kD}$ IGFBP by Western ligand blotting, similar to the IGF-induced decrease in IGFBP-4 in HFCM (Fig. 7 B). This decrease was confirmed as a loss of immunoreactive 24-kD IGFBP-4 (data not shown). As with HFCM, control incubations of cell-free SV40-HFCM did not alter the IGFBP profile and IGF-II had no effect on IGFBP-3.

To test whether SV40-transformed human fibroblasts produce an inhibitor of IGF-dependent IGFBP-4 proteolysis, combination experiments were performed with these cells and exogenous HFCM containing both IGFBP-4 and IGFBP-4 protease (Fig. 8). In a cell-free system, 5 nM IGF-II decreased IGFBP-4 in HFCM to undetectable levels (Fig. $8 \mathrm{~A}$ ). The presence of SV40-transformed human fibroblasts blocked the ability of IGF-II to decrease IGFBP-4 in HFCM (Fig. $8 \mathrm{~B}$ ). However, if SV40-transformed human fibroblasts were treated with cycloheximide $(10 \mu \mathrm{g} / \mathrm{ml})$ to inhibit ongoing protein synthesis, then the IGF-induced decrease in HFCM IGFBP-4 occurred (Fig. 8 $C)$. Cycloheximide had no effect on IGFBP-4 levels when added directly to HFCM during cell-free incubation (data not shown). Similar results were obtained in repeat experiments as well as in experiments using SV40-transformed human fibroblasts with SV40-HFCM. In contrast, the presence of normal human fibroblasts did not block the ability of IGF-II to decrease IGFBP-4 in HFCM (data not shown).

Biological consequence of IGFBP-4 proteolysis. Study of the functional role of IGFBP-4 in regulating IGF-stimulated cell growth required a cell system that was responsive to IGF-I and that would not degrade exogenous IGFBP-4 during the IGF bioassay. Normal human fibroblasts in culture are widely

\section{(A)}

\section{Cell Culture}

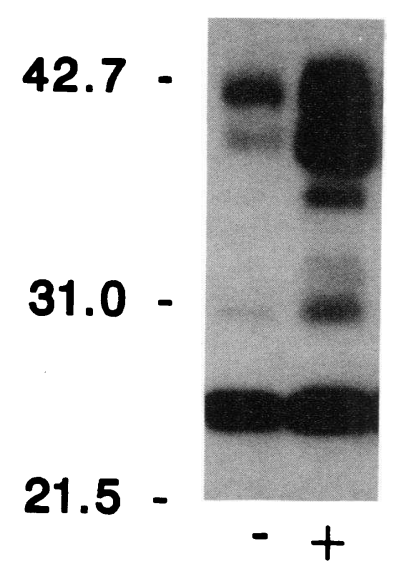

(B)

\section{Cell-free}

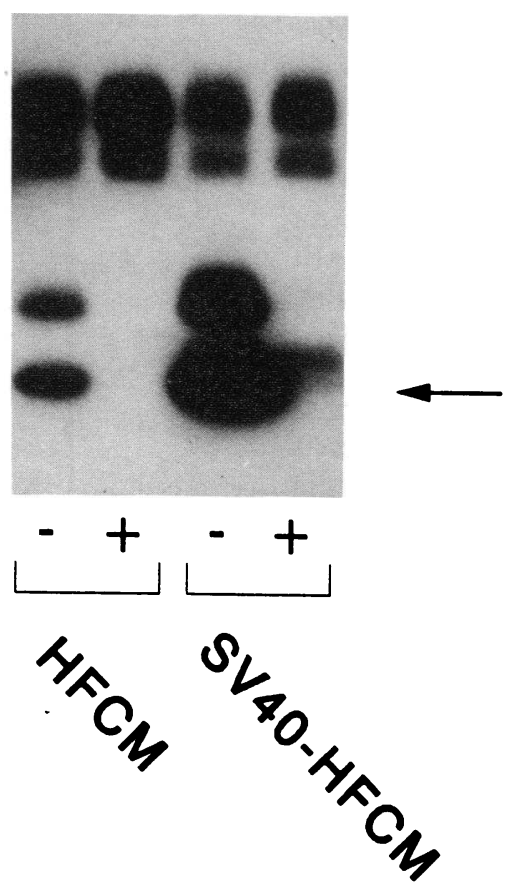

Figure 7. Western ligand blot of IGFBPs in SV40-transformed HFCM: effect of IGF-II in cell culture and cell-free incubation. $(A)$ Cell culture: SV40-transformed human fibroblasts were plated in 24 multiwells and grown to confluency. Cultures were washed and incubated $24 \mathrm{~h}$ in SFM without $(-)$ or with $(+)$ $10 \mathrm{nM}$ IGF-II. Medium was collected at the end of this incubation period. $(B)$ Cell-free: 72-h conditioned medium from normal human fibroblasts (HFCM) or SV40-transformed human fibroblasts (SV40-HFCM) was incubated under cell-free conditions without $(-)$ or with (+) $10 \mathrm{nM} \mathrm{IGF-II} \mathrm{for} 24 \mathrm{~h}$ at $37^{\circ} \mathrm{C}$. Medium samples $(50 \mu \mathrm{l})$ were analyzed by Western ligand blotting using ${ }^{125} \mathrm{I}-\mathrm{IGF}-\mathrm{I}$, as described in Fig. 1. Migration positions of molecular size markers (in $\mathrm{kD}$ ) are shown on the left. The arrow on the right indicates $24-\mathrm{kD}$ IGFBP-4. 


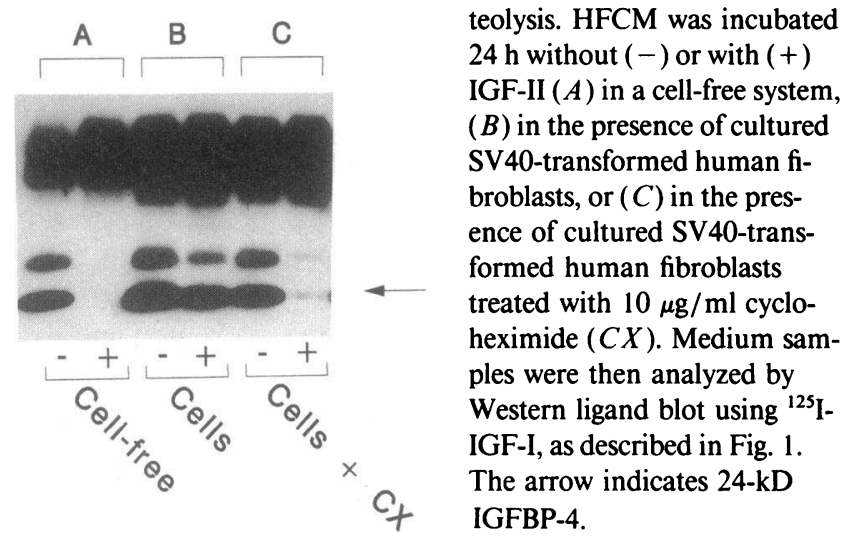

used to study various aspects of IGF physiology, but, as we have demonstrated here, these cells rapidly hydrolyze IGFBP-4 in the presence of IGF-I or IGF-II. SV40-transformed human fibroblasts appear to produce an inhibitor of IGFBP-4 proteolysis, but they are not very sensitive to IGF-I stimulation (our unpublished data). Instead, cultured bovine fibroblasts proved useful for examining the effect of IGFBP-4 on IGF-I action. These cells have abundant type I IGF receptors and respond to nanomolar concentrations of IGF-I with marked increases in $\left[{ }^{3} \mathrm{H}\right]$ AIB uptake; a half-maximal effect is obtained with approximately $1 \mathrm{nM}$ IGF-I (39). IGF-II and insulin also stimulate $\left[{ }^{3} \mathrm{H}\right] \mathrm{AIB}$ uptake in these cells by cross-reaction with the type I IGF receptor, but 4-fold and 50-fold higher concentrations of the respective peptides are needed $(39,40)$. Moreover, cultured bovine fibroblasts, like SV40-transformed human fibroblasts, block IGF-induced IGFBP-4 proteolysis ( 24 and data not shown). Therefore, we employed cultured bovine fibroblasts to investigate the effect of rhIGFBP-4 on IGF-I-stimulated $\left[{ }^{3} \mathrm{H}\right]$ AIB uptake.

rhIGFBP-4 inhibited IGF-I-stimulated $\left[{ }^{3} \mathrm{H}\right]$ AIB uptake in bovine fibroblasts in a dose-dependent manner (Fig. 9). 80\% inhibition was achieved when rhIGFBP-4 was present in fivefold molar excess [rhIGFBP-4 (10 nM): IGF-I $(2 \mathrm{nM})$ ]. In contrast to its potent inhibition of IGF-I, $10 \mathrm{nM}$ rhIGFBP-4 had no significant effect on des(1-3)IGF-I- or insulin-stimulated $\left[{ }^{3} \mathrm{H}\right] \mathrm{AIB}$ uptake. We then compared the effect of intact versus proteolyzed IGFBP-4 on IGF-I-stimulated $\left[{ }^{3} \mathrm{H}\right]$ AIB uptake in bovine fibroblasts. To obtain proteolyzed IGFBP-4, rhIGFBP-4 $(100 \mathrm{nM})$ was incubated $24 \mathrm{~h}$ at $37^{\circ} \mathrm{C}$ in $50 \mu \mathrm{l}$ proteolysis medium (cell-free HFCM with $10 \mathrm{nM}$ IGF-II). For intact IGFBP-4, rhIGFBP-4 was incubated in HFCM without IGF-II. Western ligand blotting of the incubation products confirmed that intact IGFBP-4 was retained and proteolytic processing of IGFBP-4 occurred under the appropriate conditions (data not shown). Incubation of proteolysis medium and HFCM alone was also carried out for controls. These 50- $\mu$ l samples were then added to cultured bovine fibroblasts with or without $2 \mathrm{nM}$ IGF-I in a total assay volume of $500 \mu \mathrm{l} .^{3}$ As

3. Final concentrations of the various components in the $\left[{ }^{3} \mathrm{H}\right] \mathrm{AIB}$ assay were: IGF-I ( $2 \mathrm{nM})$, rhIGFBP-4 ( $10 \mathrm{nM})$, IGF-II ( $1 \mathrm{nM})$, and $\operatorname{HFCM}(1: 10$ dilution $)$ indicated in Fig. 10, $10 \mathrm{nM}$ rhIGFBP-4 inhibited by $80 \%$ the approximately fivefold increase in $\left[{ }^{3} \mathrm{H}\right] \mathrm{AIB}$ uptake produced by 2 nM IGF-I ( $c$ vs. $a ; P<0.05$ ). However, the same concentration of proteolyzed rhIGFBP-4 had no suppressive effect on IGF-I-stimulated [ $\left.{ }^{3} \mathrm{H}\right]$ AIB uptake ( $d$ vs. $\left.b, P=\mathrm{NS}\right)$. This loss of inhibitory function was not due to IGF-II (in the proteolysis medium) binding and, therefore, decreasing the effective concentration of rhIGFBP-4, because an equivalent amount of IGF-II added directly to the assay did not dilute rhIGFBP-4's inhibitory action ( $e$ vs. $a, P<0.05$ ). In addition, the $1 \mathrm{nM}$ IGF-II contributed by the proteolysis medium had no stimulatory effect by itself ( $b$ vs. $a, P=\mathrm{NS}$ ), as would be expected based on IGF-II's low affinity for the type I IGF receptor (39, 44). Western ligand blotting of the buffer at the end of the assay documented that rhIGFBP-4 remained intact during incubation with bovine fibroblasts even in the presence of IGF-I and added IGF-II (data not shown).

\section{Discussion}

In this study, we present evidence that IGF regulation of IGFBP-4 in human fibroblasts occurs via activation of a specific IGFBP-4 protease. Furthermore, our biological studies suggest a novel mechanism by which IGF-II-induced IGFBP-4 proteolysis can promote cell responsiveness to IGF-I.

Treatment of cells with IGF peptides had been reported by us and others to decrease medium levels of IGFBP-4 (25-29, $33,34)$. In the present study we were able to reproduce the IGF-dependent decrease in IGFBP-4 in a completely cell-free

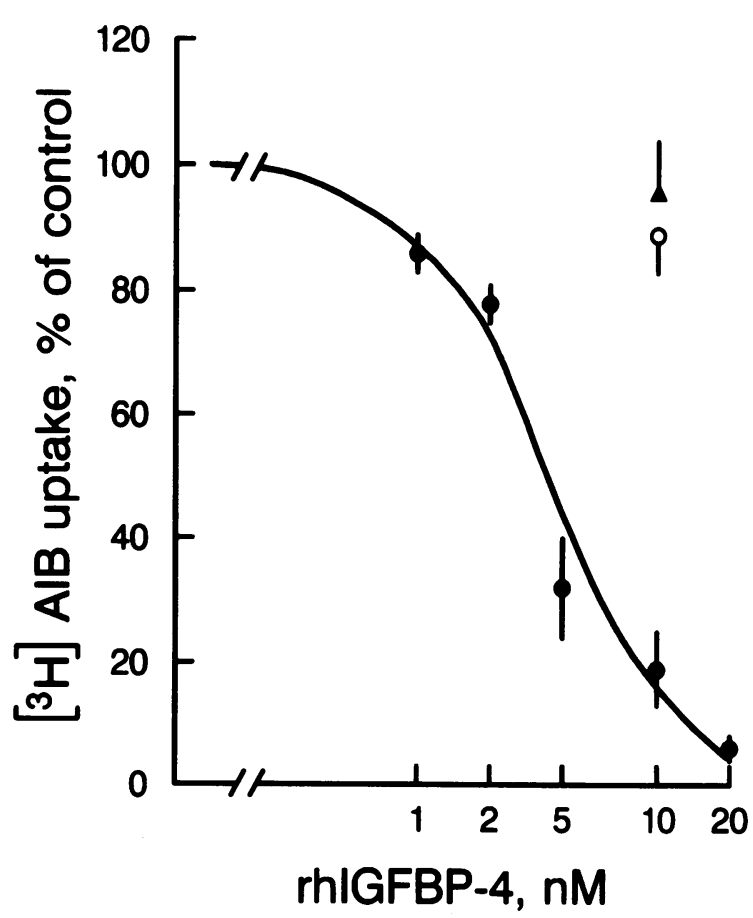

Figure 9. IGF-I-stimulated $\left[{ }^{3} \mathrm{H}\right]$ AIB uptake in bovine fibroblasts: dose effect of rhIGFBP-4. Bovine fibroblasts were incubated for $6 \mathrm{~h}$ with $2 \mathrm{nM}$ IGF-I (•), $2 \mathrm{nM}$ des( 1-3)IGF-I (O), or $100 \mathrm{nM}$ insulin $(\Delta)$ with or without rhIGFBP-4 at the indicated concentration. $\left[{ }^{3} \mathrm{H}\right]$ AIB uptake was measured as described in Methods. Results are means \pm SE of three separate experiments, expressed as percent of control (i.e., $\left[{ }^{3} \mathrm{H}\right] \mathrm{AIB}$ uptake stimulated by $2 \mathrm{nM}$ IGF-I). 


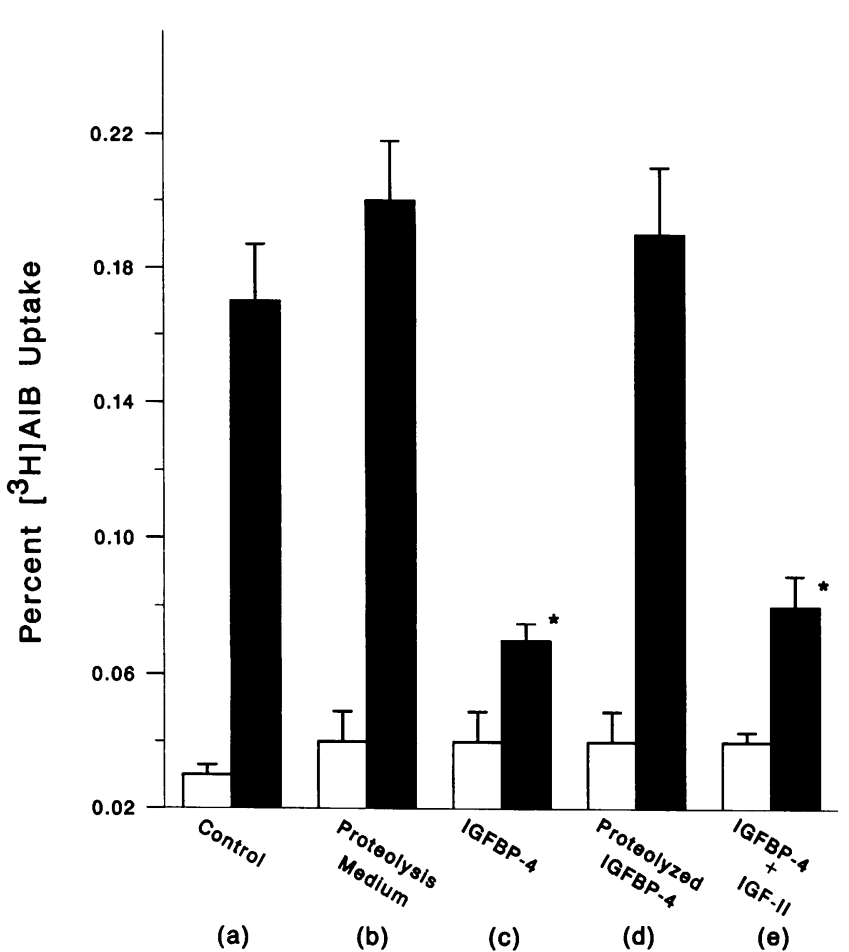

Figure 10. IGF-I-stimulated $\left[{ }^{3} \mathrm{H}\right]$ AIB uptake in bovine fibroblasts: effect of intact versus proteolyzed rhIGFBP-4. [ ${ }^{3} \mathrm{H}$ ]AIB uptake by bovine fibroblasts was measured $6 \mathrm{~h}$ after stimulation without (open bars) or with (solid bars) 2 nM IGF-I and the indicated experimental additions. ( $a$ ) Control: HFCM. ( $b$ ) Proteolysis medium: HFCM / 10 nM IGF-II. (c) IGFBP-4: 100 nM rhIGFBP-4 in HFCM. (d) Proteolyzed IGFBP-4: $100 \mathrm{nM}$ rhIGFBP-4 in HFCM/ $10 \mathrm{nM}$ IGF-II. Additions in $a-d$ had been preincubated at $37^{\circ} \mathrm{C}$ for $24 \mathrm{~h}$ and were then added as $50 \mu \mathrm{l}$ for a total assay volume of $500 \mu \mathrm{l}$. For $e$ IGFBP-4 + IGF-II, $100 \mathrm{nM}$ rhIGFBP-4 was preincubated in HFCM but IGF-II was added directly to the cell assay for a final concentration of $1 \mathrm{nM}$. Results are means \pm SE of three experiments. *Significant effect of IGFBP-4 $(P<0.05)$

system, demonstrating that the IGF effect can be exerted independent of any changes in IGFBP-4 expression or secretion. Thus, the direct addition of IGF-II to cell-free HFCM and incubation for as little as $2 \mathrm{~h}$ at $37^{\circ} \mathrm{C}$ resulted in significant loss of detectable IGFBP-4, as assessed by Western ligand blot. Only IGF peptides were able to elicit this response; no other growth factors tested, including insulin, growth hormone, epidermal growth factor, or various steroid hormones, had any effect on IGFBP-4 levels.

Involvement of a protease in HFCM was indicated by several lines of evidence. First, binding of IGF peptide to IGFBP-4 in HFCM could not by itself explain the results because the binding reaction proceeded at $4^{\circ} \mathrm{C}$ (standard Western ligand blot procedure), whereas the IGF-induced decrease in IGFBP4 did not. Second, rhIGFBP-4 binds IGF-II with high affinity but there was no loss of rhIGFBP-4 during incubation with IGF-II in unconditioned medium. Nevertheless, IGF-II could promote a marked decrease in rhIGFBP-4 during incubation in the presence of cell-free HFCM. Using Western immunoblotting, we confirmed that under these latter conditions intact rhIGFBP-4 (24 kD nonreduced; $32 \mathrm{kD}$ reduced) was lost and immunoreactive bands of lower mol wt ( 18 and $14 \mathrm{kD}$ ) appeared. Also, iodinated rhIGFBP-4 treated with IGF-II and cell-free HFCM yielded radiolabeled 18- and 14-kD fragments. Finally, IGF-induced decreases in IGFBP-4 levels in HFCM could be blocked by protease inhibitors, specifically EDTA, 1, 10 phenanthroline, and benzamidine. The data thus implicate a type of cation-dependent protease in HFCM which, under physiological conditions and in the presence of IGF peptide, can hydrolyze IGFBP-4.

This protease appears to have a strict IGF requirement since IGFBP-4 levels were unaltered when conditioned medium was incubated without IGFs. Of the natural and mutant IGFs examined, IGF-II was consistently the most effective and could catalyze IGFBP-4 proteolysis to completion when incubated with IGFBP-4 at a 0.25:1 molar concentration. IGF-II bound IGFBP-4 with high affinity. Nevertheless, relative affinity of different IGFs for IGFBP-4 did not necessarily correspond to ability to regulate IGFBP-4 levels. The most striking discordancy between IGFBP-4 binding and proteolysis was seen with des(1-3)IGF-I. This IGF-I variant had low affinity for IGFBP-4, as assessed by competition with ${ }^{125} \mathrm{I}-\mathrm{IGF}-\mathrm{I}$ for binding to rhIGFBP-4 and by failure of rhIGFBP-4 to inhibit des( 1-3)IGF-I action; however, des( 1-3)IGF-I effectively promoted the degradation of endogenous and recombinant IGFBP-4. Conversely, [1-27, Gly 4 , 28-70]IGF-I bound IGFBP-4 with high affinity, but was a comparatively weak inducer of IGFBP-4 proteolysis. Our results suggest that IGF peptides may directly activate the IGFBP-4 protease. However, different conditions were employed to measure IGFBP-4 binding affinity and catalytic activity, and a proteolytic mechanism involving IGF binding to IGFBP-4 cannot be ruled out.

The IGF-dependent protease is specific for IGFBP-4. Cellfree incubation with or without IGF-II had no effect on other IGFBPs present in HFCM or on IGFBP-1, IGFBP-2, IGFBP-3, IGFBP-5, and IGFBP-6 added to HFCM. Therefore, it is unlikely to be the same as the recently described cation-dependent IGFBP-3 protease $(19,20)$ or the cation-independent serine protease, plasmin, which has been implicated in the proteolysis of IGFBP-1 (21). Although the protease in HFCM could be active against different IGFBP substrates under different conditions, it is more probable that the protease responsible for IGFBP-4 processing in this study is the newest member of a growing family of IGFBP-specific proteases. Its uniqueness may derive from its IGF activation, a feature not specifically identified with the other recognized IGFBP proteases.

Preliminary identification of an inhibitor involved in the posttranslational regulation of IGFBP-4 derived from observations that, unlike findings with normal human fibroblasts, IGF-II treatment of cultured SV40-transformed human fibroblasts did not bring about a reduction in medium levels of IGFBP-4 (33 and Fig. $7 A$ ). However, when the conditioned media from these transformed cell cultures were treated with IGF-II in a cell-free system, a marked decrease in IGFBP-4 levels occurred. These results indicated that an IGF-dependent IGFBP-4 protease is present in the conditioned medium from SV40-transformed human fibroblasts as well as a potent inhibitor of IGFBP-4 proteolysis. Effective restraint of IGFBP-4 proteolysis appeared to require the continued synthesis and/or secretion of inhibitor. This hypothesis was tested by incubating HFCM (source of IGFBP-4 and IGFBP-4 protease) with or without IGF-II in the presence of SV40-transformed human fibroblasts. As we showed, SV40-transformed human fibroblasts prevented the decrease in HFCM IGFBP-4 with the addition of IGF-II. However, treatment of SV40-transformed hu- 
man fibroblasts with cycloheximide, an inhibitor of protein synthesis, allowed the IGF-II-dependent decrease in IGFBP-4 to proceed. These results suggest that SV40-transformed human fibroblasts produce an inhibitory protein involved in the IGFBP-4 proteolytic reaction. However, other explanations cannot be discounted at this time, and, like the IGFBP-4 protease itself, the identity of this inhibitor(s) awaits more thorough characterization.

IGF-controlled proteolysis of IGFBP-4 may be involved in a wide variety of biological systems. By using cell-free assay, we could demonstrate IGFBP-4 protease activity in medium conditioned by normal and transformed adult human fibroblasts. Preliminary studies indicate the presence of a similar protease in fetal human, bovine, rat, and sheep fibroblasts as well as human decidual cells $(45,46$, and our unpublished data). We have previously reported that incubation of normal human osteoblast-like cells with IGF-I or IGF-II results in an $80 \%$ decrease in levels of 24-kD IGFBP in the medium (25), and have confirmed these results under cell-free conditions (our submitted manuscript). In addition, IGF-induced decreases in 24-kD IGFBPs have been noted in cultures of human decidual cells, human breast carcinoma cells, and a rat neuroblastoma cell line $(26,28,29,41)$. It may be that posttranslational regulation of IGFBP-4 is as important as IGFBP-4 expression in determining IGFBP-4 availability.

In biological studies using cultured bovine fibroblasts, IGFBP-4 blocked IGF-I-stimulated $\left[{ }^{3} \mathrm{H}\right]$ AIB uptake when present in 5-fold molar excess. IGFBP-4 had no significant effect on $\left[{ }^{3} \mathrm{H}\right]$ AIB uptake stimulated by des(1-3) IGF-I or insulin, peptides with little or no affinity for IGFBP-4. These findings are in agreement with reports that IGFBP-4 inhibits IGF action in vitro by sequestering the peptide and preventing receptor interaction $(8,26,30,32)$. Our study further demonstrated that relatively low amounts of IGF-II (molar ratio 0.1:1 [IGFII/IGFBP-4]) induced IGFBP-4 proteolysis with consequential loss of IGFBP-4 inhibitory function. IGF-II was more effective than IGF-I in activating IGFBP-4 proteolysis whereas IGFI is more potent than IGF-II in activating type I IGF receptor signaling $(39,40,44)$, suggesting a novel mechanism for concerted control of cell growth by IGF-I and IGF-II. Thus at low levels, IGF-II could facilitate the breakdown of IGF inhibitory proteins (IGFBP-4), thereby increasing the availability of IGFI for receptor interaction. In this way, stimulatory effects of IGF-II may reflect ability to regulate IGFBP-4, independent of IGF-II cross-reactivity with the type I IGF receptor. This mechanism could play a significant role in bone with its high concentration of IGF-II in bone matrix (47), osteoblastic production of IGFBP-4 $(7,25)$, and IGF-regulated IGFBP-4 protease activity ( 25 and unpublished results). On the other hand, if intact IGFBP-4 is an important inhibitor of IGF-I-stimulated growth, then cell types which secrete IGFBP-4 but block localized IGFBP-4 proteolysis (via inhibitors of proteolysis and/or decreased IGFBP-4 protease production ) would be expected to have limited responsiveness to IGFs. However, if growth requirements for IGFs are reduced (e.g., with transformation), then the resulting effect could be inhibition of adjacent cell growth and facilitated invasion into surrounding normal tissue. Thus, constraints on IGFBP-4 proteolysis could provide the potential for preferential tumor growth. It may be significant that IGFBP-4 is secreted by a variety of transformed and malignant cells and elevated levels of IGFBP-4 are, in many cases, associated with a transformed phenotype $(25,29$, 31-34).

In conclusion, identification of IGFBP proteases, especially those regulated by IGF peptides, adds a whole new dimension of complexity to our understanding of IGF physiology. Further studies are needed to evaluate the significance of our findings with respect to normal and abnormal cell growth.

\section{Acknowledgments}

We are grateful for the dedication and excellent technical assistance of Laurie Bale, Jay Clarkson, and Guitty Eghbali-Fatourechi.

This work was supported, in part, by National Institutes of Health grant DK-44880 (Dr. Conover) and the Mayo Foundation.

\section{References}

1. Lee, Y.-L., R. L. Hintz, P. M. James, P. D. K. Lee, J. E. Shively, and D. R. Powell. 1988. Insulin-like growth factor (IGF) binding protein complementary deoxyribonucleic acid from human $\mathrm{HEP}$ Gc2 hepatoma cells: predicted protein sequence suggests an IGF binding domain different from those of the IGF-I and IGF-II receptors. Mol. Endocrinol. 2:404-411.

2. Binkert, C., J. Landwehr, J.-L. Mary, J. Schwander, and G. Heinrich. 1989. Cloning, sequence analysis and expression of a cDNA encoding novel insulin-like growth factor binding protein (IGFBP-2). EMBO (Eur. Mol. Biol. Organ.) J. 8:2497-2502.

3. Brown, A. L., L. Chiariotti, C. C. Orlowski, T. Mehlman, W. H. Burgess, E. J. Ackerman, C. B. Bruni, and M. M. Rechler. 1989. Nucleotide sequence and expression of a cDNA clone encoding a fetal rat binding protein for insulin-like growth factors. J. Biol. Chem. 264:5148-5154.

4. Wood, W. I., G. Cachianes, W. J. Henzel, G. A. Winslow, S. A. Spencer, R. Hellmiss, J. Martin, and R. C. Baxter. 1988. Cloning and expression of the growth hormone-dependent insulin-like growth factor-binding protein. Mol. Endocrinol. 2:1176-1185.

5. Kiefer, M. C., F. R. Masiarz, D. M. Bauer, and J. Zapf. 1991. Identification and molecular cloning of two new $30-\mathrm{kDa}$ insulin-like growth factor binding proteins isolated from adult human serum. J. Biol. Chem. 266:9043-9049.

6. Shimasaki, S., F. Uchiyama, M. Shimonaka, and N. Ling. 1990. Molecular cloning of the cDNAs encoding a novel insulin-like growth factor-binding protein from rat and human. Mol. Endocrinol. 4:1451-1458.

7. LaTour, D., S. Mohan, T. A. Linkhart, D. J. Baylink, and D. D. Strong. 1990. Inhibitory insulin-like growth factor-binding protein: cloning, complete sequence, and physiological regulation. Mol. Endocrinol. 4:1806-1814.

8. Kiefer, M. C., C. Schmid, M. Waldvogel, I. Schlapfer, E. Futo, F. R. Masiarz, K. Green, P. J. Barr, and J. Zapf. 1992. Characterization of recombinant human insulin-like growth factor binding proteins 4,5 and 6 produced in yeast. $J$. Biol. Chem. 257:2592-2599.

9. Froesch, E. R., C. Schmid, J. Schwander, and J. A. Zapf. 1985. Actions of insulin-like growth factors. Rev. Physiol. Biochem. Pharmacol. 47:443-467.

10. Baxter, R. C., and J. L. Martin. 1989. Binding proteins for the insulin-like growth factors: structure, regulation and function. Prog. Growth Factor Res. 1:49-68.

11. Rosenfeld, R. G., G. Lamson, H. Pham, Y. Oh, C. Conover, D. D. De Leon, S. M. Donovan, I. Ocrant, and L. Giudice. 1990. Insulin-like growth factor binding proteins. Recent Prog. Horm. Res. 46:99-163.

12. Powell, D. R., A. Suwanichkul, M. L. Cubbage, L. A. DePaolis, M. B. Snuggs, and P. D. K. Lee. 1991. Insulin inhibits transcription of the human gene for insulin-like growth factor binding protein-1. J. Biol. Chem. 266:1886818876.

13. Unterman, T. G., D. T. Oehler, L. J. Murphy, and R. G. Lacson. 1991. Multihormonal regulation of insulin-like growth factor-binding protein-1 in rat H4IIE hepatoma cells: The dominant role of insulin. Endocrinology. 128:26932701.

14. Orlowski, C. C., G. T. Ooi, and M. M. Rechler. 1990. Dexamethasone stimulates transcription of the insulin-like growth factor-binding protein-1 gene in H4-II-E rat hepatoma cells. Mol. Endocrinol. 4:1592-1599.

15. Böni-Schnetzler, M., C. Schmid, J.-L. Mary, B. Zimmerli, P. J. Meier, J. Zapf, J. Schwander, and E. R. Froesch. 1990. Insulin regulates the expression of the insulin-like growth factor binding protein $2 \mathrm{mRNA}$ in rat hepatocytes. Mol. Endocrinol. 4:1320-1326.

16. Bale, L. K., and C. A. Conover. 1992. Regulation of insulin-like growth factor binding protein-3 messenger ribonucleic acid expression by insulin-like growth factor I. Endocrinology. 131:608-614.

17. Bachrach, L. K., F. R. Liu, G. N. Burrow, and M. C. Eggo. 1989. Charac- 
terization of insulin-like growth factor-binding proteins from sheep thyroid cells. Endocrinology. 125:2831-2838.

18. Jones, J. I., A. J. D'Ercole, C. Camacho-Hubner, and D. R. Clemmons. 1991. Phosphorylation of insulin-like growth factor (IGF)-binding protein 1 in cell culture and in vivo: effects on affinity for IGF-I. Proc. Natl. Acad. Sci. USA. 88:7481-7485.

19. Giudice, L. C., E. M. Farrell, H. Pham, G. Lamson, and R. G. Rosenfeld. 1990. Insulin-like growth factor binding proteins in maternal serum throughout gestation and in the puerperium: effects of a pregnancy-associated serum protease activity. J. Clin. Endocrinol. Metab. 71:806-816.

20. Hossenlopp, P., B. Segovia, C. Lassarre, M. Roghani, M. Bredon, and M. Binoux. 1990. Evidence of enzymatic degradation of insulin-like growth factorbinding proteins in the $150 \mathrm{~K}$ complex during pregnancy. J. Clin. Endocrinol. Metab. 71:797-805.

21. Campbell, P. G., J. F. Novak, T. B. Yanosick, and J. H. McMaster. 1992. Involvement of the plasmin system in dissociation of the insulin-like growth factor-binding protein complex. Endocrinology. 130:1401-1412.

22. Erickson, G. F., A. Nakatani, N. Ling, and S. Shimasaki. 1992. Cyclic changes in insulin-like growth factor-binding protein-4 messenger ribonucleic acid in the rat ovary. Endocrinology. 130:625-636.

23. Conover, C. A., F. Liu, D. Powell, R. G. Rosenfeld, and R. L. Hintz. 1989 Insulin-like growth factor binding proteins from cultured human fibroblasts: characterization and hormonal regulation. J. Clin. Invest. 83:852-859.

24. Conover, C. A. 1990. Regulation of insulin-like growth factor (IGF) binding protein synthesis by insulin and IGF-I in cultured bovine fibroblasts. Endocrinology. 126:3139-3145.

25. Hassager, C., L. A. Fitzpatrick, E. M. Spencer, B. L. Riggs, and C. A Conover. 1992. Basal and regulated secretion of insulin-like growth factor binding proteins in osteoblast-like cells is cell line specific. J. Clin. Endocrinol. Metab. 75:228-233

26. Cheung, P. T., E. P. Smith, S. Shimasaki, N. Ling, and S. D. Chernausek. 1991. Characterization of an insulin-like growth factor binding protein (IGFBP4) produced by the B104 rat neuronal cell line: chemical and biological properties and differential synthesis by sublines. Endocrinology. 129:1006-1015.

27. Clemmons, D. R., M. A. Cascieri, C. Camacho-Hubner, R. H. McCusker, and M. L. Bayne. 1990. Discrete alterations of the insulin-like growth factor I molecule which alter its affinity for insulin-like growth factor-binding proteins result in changes in bioactivity. J. Biol. Chem. 265:12210-12216.

28. Clemmons, D. R., K. M. Thrailkill, S. Handwerger, and W. H. Busby, Jr. 1990. Three distinct forms of insulin-like growth factor binding proteins are released by decidual cells in culture. Endocrinology. 127:643-650.

29. Camacho-Hubner, C., R. H. McCusker, and D. R. Clemmons. 1991. Secretion and biological actions of insulin-like growth factor binding proteins in two human tumor-derived cell lines in vitro. J. Cell. Physiol. 148:281-289.

30. Mohan, S., C. M. Bautista, J. Wergedal, and D. J. Baylink. 1989. Isolation of an inhibitory insulin-like growth factor (IGF) binding protein from bone cellconditioned medium: a potential local regulator of IGF action. Proc. Natl. Acad. Sci. USA. 86:8338-8342.

31. Perkel, V. S., S. Mohan, D. J. Baylin, and T. A. Linkhart. 1990. An inhibitory insulin-like growth factor binding protein (In-IGFBP) from human prostatic cell conditioned medium reveals $\mathrm{N}$-terminal sequence identity with bone derived In-IGFBP. J. Clin. Endocrinol. Metab. 71:533-535.

32. Culouscou, J.-M., and M. Shoyab. 1991. Purification of a colon cancer cell growth inhibitor and its identification as an insulin-like growth factor binding protein. Cancer Res. 51:2813-2819.

33. Conover, C. A. 1991. A unique receptor-independent mechanism by which insulinlike growth factor I regulates the availability of insulinlike growth factor binding proteins in normal and transformed human fibroblasts. J. Clin. Invest. 88:1354-1361.

34. Neely, E. I., and R. G. Rosenfeld. 1992. Insulin-like growth factors (IGFs) reduce IGF-binding protein-4 (IGFBP-4) concentration and stimulate IGFBP-3 independently of IGF receptors in human fibroblasts and epidermal cells. Endocrinology. 130:985-993.

35. Kiefer, M. C., C. Schmid, M. Waldvogel, I. Schlapfer, E. Futo, F. R. Masiarz, K. Green, P. J. Barr, and J. Zapf. Characterization of recombinant human insulin-like growth factor binding proteins 4,5 , and 6 produced in yeast. Growth Regul. In press.

36. Hossenlopp, P., D. Seurin, B. Segovia-Quinson, S. Hardouin, and M Binoux. 1986. Analysis of serum insulin-like growth factor binding proteins using Western blotting: use of the method for titration of the binding proteins and competitive binding studies. Anal. Biochem. 154:138-143.

37. Hancock, K., and V. C. W. Tsang. 1983. India ink staining of proteins on nitrocellulose paper. Anal. Biochem. 133:157-162.

38. Rosenfeld, R. G., and L. A. Dollar. 1982. Characterization of the somatomedin-C/insulin-like growth factor I (SM-C/IGF-I) receptor on cultured human fibroblast monolayers: regulation of receptor concentrations by SM-C/IGF-I and insulin. J. Clin. Endocrinol. Metab. 55:434-439.

39. Conover, C. A., M. Ronk, F. Lombana, and D. R. Powell. 1990. Structura and biological characterization of bovine insulin-like growth factor binding protein-3. Endocrinology. 127:2795-2803.

40. Conover, C. A. 1992. Potentiation of insulin-like growth factor (IGF) action by IGF-binding protein-3: Studies of underlying mechanism. Endocrinology. 130:3191-3199.

41. Ceda, G. P., P. J. Fielder, W. J. Henzel, A. Louie, S. M. Donovan, A. R Hoffman, and R. G. Rosenfeld. 1991. Differential effects of insulin-like growth factor (IGF)-I and IGF-II on the expression of IGF binding proteins (IGFBPs) in a rat neuroblastoma cell line: isolation and characterization of two forms of IGFBP-4. Endocrinology. 128:2815-2824.

42. Conover, C. A., B. K. Baker, and R. L. Hintz. 1989. Cultured human fibroblasts secrete insulin-like growth factor IA prohormone. J. Clin. Endocrinol. Metab. 69:25-30.

43. Clemmons, D. R., and J. J. Van Wyk. 1985. Evidence for a functional role of endogenously produced somatomedinlike peptides in the regulation of DNA synthesis in cultured human fibroblasts and porcine smooth muscle cells. J. Clin. Invest. 75:14-18.

44. Nissley, P., and W. Lopaczynski. 1991. Insulin-like growth factor receptors. Growth Factors. 5:29-43.

45. Fowlkes, J., and M. Freemark. 1992. Regulation of high affinity insulinlike growth factor II (IGF-II) binding proteins: a novel IGF-dependent protease regulating IGFBP-4. 74th Annual Meeting of the Endocrine Society, 24-27 June 1992, San Antonio, TX (abstract 1611).

46. Cheung, P. T., S. Myers, and S. D. Chernausek. 1992. IGF-I-induced proteolysis of IGFBP-4 in human decidual cells. 74th Annual Meeting of the Endocrine Society, 24-27 June 1992, San Antonio, TX (abstract 950).

47. Bautista, C. M., S. Mohan, and D. J. Baylink. 1990. Insulin-like growth factors I and II are present in the skeletal tissues of ten vertebrates. Metab. Clin. Exp. 39:96-100. 